IJMS 17 (1), 87-106 (2010)

\title{
PSYCHOMETRIC PROPERTIES OF ORGANISATIONAL STRUCTURE SCALE IN THE MALAYSIAN PUBLIC SERVICE AGENCIES: PRELIMINARY RESULTS
}

\author{
JOHANIM JOHARI \\ KHULIDA KIRANA YAHYA \\ ABDULLAH OMAR \\ UUM College of Business \\ Universiti Utara Malaysia
}

\begin{abstract}
Organisational structure has been assessed with various different scales resulting in inconsistencies in the measures of this construct. Hence, a re-conceptualisation of the organisational structure construct is crucial due to the fact that researchers have thus far provided inconclusive agreement on what dimensions should be included in measuring organisational structure, although many studies have conceptualised organisational structure as a multidimensional construct. This study attempted to examine the psychometric properties of the organisational structure construct by integrating four subscales - decision making, hierarchy of authority, job codification, and rule observation. A priori proposition was made that organisational structure measurement could be explained by four of the hypothesised dimensions. SPSS version 12 and AMOS 4 were used to analyse the data. Findings supported the hypothesis that organisational structure can be measured by the four aforementioned subscales. Findings also showed acceptable internal consistency reliability for the overall and the four specific subscales of organisational structure latent construct.
\end{abstract}

Keywords: Organisational structure; psychometric properties; exploratory factor analysis; confirmatory factor analysis; Malaysian Public Service.

\begin{abstract}
ABSTRAK
Struktur organisasi telah diukur dengan menggunakan pelbagai skala dan menyebabkan pengukuran konstruk ini tidak konsisten. Walaupun pelbagai kajian mengkonsepkan struktur organisasi sebagai konstruk yang mempunyai pelbagai dimensi, para penyelidik setakat ini masih belum dapat membuat persetujuan tentang faktor apakah yang sesuai digunakan dalam mengukur struktur organisasi.
\end{abstract}


Kajian ini cuba mengkaji nilai psikometrik bagi konstrukstruktur organisasi dengan menggabungkan empat subskala: pembuatan keputusan, hierarki kuasa, kodifikasi kerja, dan pemerhatian peraturan. SPSS versi 12 dan AMOS 4 telah digunakan untuk menganalisis data. Kajian menyokong hipotesis iaitu struktur organisasi boleh diukur dengan menggunakan empat faktor. Hasil kajian juga mendapati nilai kebolehpercayaan yang boleh diterima bagi empat subskala bagi faktor struktur organisasi.

Kata kunci: struktur organisasi; nilai psikometrik; analisis faktor; perkhidmatan awam Malaysia.

\section{Introduction}

The Malaysian Public Service is the single largest employer employing about $10.6 \%$ of the nation's total workforce (Public Service Department, 2007). The sizeable human capital has to be mobilised and managed effectively and efficiently to unleash their full potential for long term benefits of the nation. Energy and resources should be focused on transforming human capital in the public service by strengthening their knowledge, skills, abilities, characteristics, and competencies needed to manage and lead the public administration of the future (Malek, 2006). Reforming the public service and transforming its human capital are efforts prerequisite to provide excellent and high quality service to its stakeholders and clientele in the $21^{\text {st }}$ century.

- Notwithstanding the tremendous reformation being made and great emphasis being placed on performance, the Malaysian public service has so far failed to achieve high quality standards especially in terms of service delivery. This is supported by the fact that there is a decline in the Malaysian Public Sector competence compared to other Asian countries. In 2004, Malaysia was ranked $18^{\text {th }}$ place in the World Competitiveness Report from the Geneva-based Institute for Management Development (IMD), but this ranking has dropped to the $28^{\text {th }}$ place in 2005 ("IMD World Competitiveness - Report", 2005 \& 2006). In 2006, the Malaysian Public Sector has managed to slightly improve the ranking to the $22^{\text {nd }}$ place, nonetheless the ranking in terms of government efficiency has deteriorated from $16^{\text {th }}$ place in 2004 to $26^{\text {th }}$ in 2006 ("IMD World Competitiveness Report", 2006). In fact, the overall ranking has dropped slightly to the $23^{\text {rd }}$ place in 2007 ("IMD World Competitiveness Report", 2007). In the local context, the Malaysian Public Service has recorded 58\% increase in formal complaints from the public in 2005 (Siddiquee, 2006). Specifically, a total of 2,707 complaints related to performance had been received, which includes delays in service provision, unfair actions/decisions of the administrators, abuse of power, 


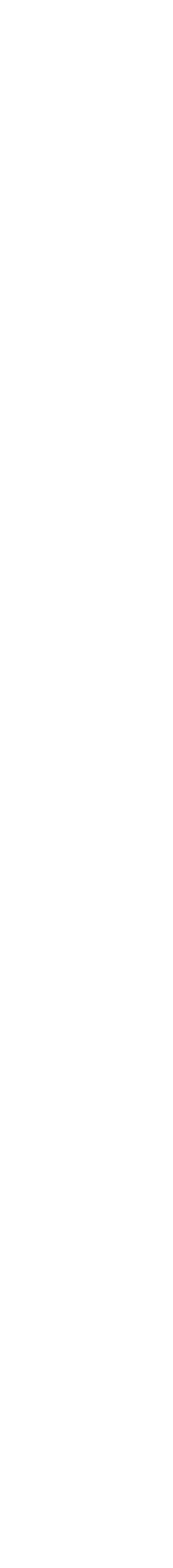

misconduct of the officials, and failure to enforce rules. Even though the number of complaints has dropped slightly from 2,792 in 2004 to 2,707 in 2005 , it should be noted that complaints on unsatisfactory service quality have almost doubled from 2.91 to 4.43\% (Public Complaints Bureau, 2005). Until September 2007, the overall number of complaints has dropped from 3,397 in 2006 to 2,378 but the number of complaints on unsatisfactory service quality has tripled to15.60 and $15.53 \%$ in 2006 and 2007, respectively, compared to the preceding years (Public Complaints Bureau, 2007). This is consistent to Siddiquee's (2006) assertion that the Malaysian Public Service has long been criticised for its inflexibility, ineffective accountability, and public officials' poor performance. Hence, it can be concluded that problems related to service quality in the public sector originated from the public officials' poor performance, which also mirrors the overall performance of the public sector.

Various factors related to public servants' poor performance have been highlighted in the literature, such as the use of inappropriate performance indicators (Givan, 2005), challenges for public servants to fulfill the need of multiple stakeholders (Black, Briggs, \& Keogh, 2001), traits and behaviours of public servants that may influence customer satisfaction at different levels (George \& Hegde, 2004), performance gap not identified by the top management (Mwita, 2000), vague organisational goals (Pandey \& Rainey, 2006), pervasive effect of red tape (Pandey \& Welch, 2005; Siddiquee, 2006), and organisational politics and unfair reward allocation (Siddiquee, 2006). It was also noted that among the perceived weaknesses in the public sector are lack of communication skills among public servants, lack of leadership commitment in managing human resources at the agency level, resistance to change among public servants, difficulty in handling and dealing with poor performers due to lack of exit policy, over-centralised decision making, lack of systematic succession planning that leads to unclear career paths, and lack of focus on human resource management by top management in the public sector (Malek, 2006). Based on the aforementioned empirical findings, it is crucial to note that most factors reported to have impacted job performance in the public sector were environmental or organisational factors that are beyond the control of incumbents performing the job. On the same note, Williams (2002) asserted that system factors, besides person factors, are of substantial value in job performance research. System factors deals with factors in the organisational environment and work design that may affect individual job performance (Williams, 2002). As such, organisational structure can be considered as the system factors that influences job performance of the public servants. Hence, researchers should consider examining organisational factors, besides person factors, in understanding factors influencing job performance in the public sector.

IJMS 17 (1), 87-106 (2010) 
Organisational structure has been predicted as one of the significant determinants of job performance, especially in the public sector. This is due to the fact that the public sector has always been associated with ineffective job design and bureaucratic nature, which have resulted in poor performance among public servants (Malek, 2006; Pandey \& Welch, 2005; Siddiquee, 2006). On the same note, Motowidlo, Borman, and Schmit (1997) claimed that job performance is affected by many extraneous factors not under the job incumbent's control. This is consistent with results from a meta-analysis by Rhoades and Eisenberg (2002), which found that organisational factors, as opposed to personal dispositions, were reported to be the stronger predictors of performance. This indicates that organisational factors are of significant value in predicting job performance. It has also been reported that organisational structure as well may affect the work engagement and intrinsic job satisfaction (Sarros, Tanewski, Winter, Santora, \& Densten, 2002). Organisational environments are also found to have affected employees' self-efficacy which is a crucial element in enhancing task and contextual performance (George \& Jones, 1997; Speir \& Frese, 1997). In accordance to Weber's (1947) Bureaucracy theory an organisational structure with centralised decision making, centralised hierarchy of authority, formalised job codification, and formalised rule observation is related to positive work attitude. In other words, organisational structure could enhance work attitude such as work involvement and indirectly improve job performance.

\section{Objectives of the Study}

Studies on organisational structure have adopted various different measures in capturing the organisational structure construct. As such, there is a need to develop a more comprehensive instrument that can capture clearly the aforementioned construct. This study examined the construct validity of the organisational structure items in the Malaysian Public Service agencies setting by integrating four subscales - decision making, hierarchy of authority, job codification, and rule observation, as suggested in the literature.

We examined the construct validity of the organisational structure instrument which also served as a preliminary investigation of the psychometric properties of the Malay language version of the organisational structure instrument with a sample of respondents from the Malaysian Public Service agencies. While most empirical evidence, for instance Adler and Borys (1996), Dewar, Whettan, and Boje (1980), and Tata and Prasad (2004), examined internal consistency reliability and face validity of the instrument, this study intended to provide empirical scrutiny by examining internal consistency reliability as well as construct validity of the organisational structure instrument. More specifically, the objectives of this study were twofold: firstly, to assess the internal consistency reliability of

90 IJMS 17 (1), 87-106 (2010) 


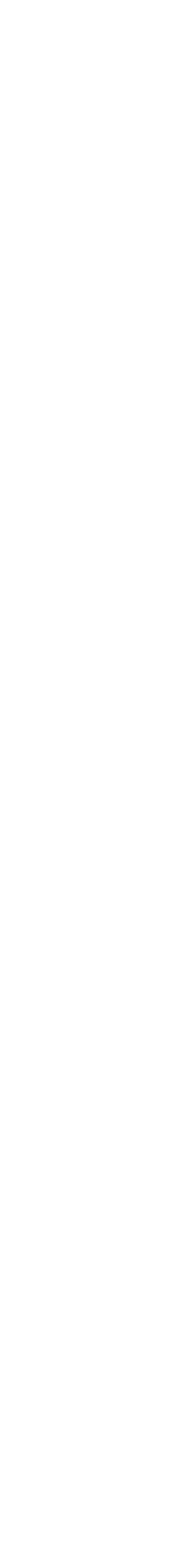

the overall organisational structure construct and each dimension under the construct; and secondly, to assess the construct validity of the organisational structure instrument utilising exploratory and confirmatory factor analytic procedures. The items and dimensions of the organisational structure scale were developed and adapted from a seminal work of Hage and Aiken (1967). The measurement assessed four dimensions of organisational structure: decision making, hierarchy of authority, job codification, and rule observation.

\section{Literature Review}

\section{Conceptual Background of Organisational Structure}

The conception of organisational structure construct has come long way since it was first established by Hage and Aiken (1967). This latent construct has been defined as practices being undertaken in an organisation with regard to policies, procedures, and rules (Hage \& Aiken, 1967). Two important features of organisational structure are formalisation and centralisation, which can further be divided into four sub dimensions: decision making, hierarchy of authority, job codification, and rule observation (Hage \& Aiken, 1967). Under the formalisation construct, job codification has been defined as the level to which an organisation precisely spells out rules and procedures related to jobs in different situations while rule observation refers to the extent to which an organisation rigidly adheres to the rules and procedures. In other words, this construct measures how far employees are supervised in ensuring that they are not committing any offense against the company's rules and regulations (Hage \& Aiken, 1967). Centralisation deals with the amount of power distributed among employees of various positions. This variable is measured in terms of hierarchy of authority and participation in decision making. According to Hage and Aiken (1967), the former examines the level subordinates are reliant upon their supervisors in decision making while the latter identifies the level of employees' involvement in decisions on resource allocation and policy formation. The concept of organisational structure developed by Hage and Aiken (1967) has been used widely in examining and explaining organisational structure factors in many empirical studies.

\section{Measurement of Organisational Structure Construct}

Both conceptualisation and measurement of organisational construct by Hage and Aiken (1967) has been used extensively in assessing the organisational structure factor in many empirical studies in different research settings. Nevertheless, it is crucial to note that some of the items need to 
undergo decentering and back translation procedure prior to adopting the instrument in different contexts. It was decades later that some scholars added new ideas to further improve the understanding of this factor, for example Adler and Borys (1996), Agarwal (1993), and Bodewes (2002). The researchers merely explicated outcomes of organisational structures in different settings without introducing any new concepts to the notion of organisational structure. In fact, all of the explanations and arguments in their studies were based on Hage and Aiken's research and measurement.

Hence, given the fact that Hage and Aiken's (1967) measurement of organisational structure has continuously become the main interest of academia in the respective area, this study intends to examine the psychometric properties of the organisational structure latent construct by assessing internal consistency reliability and construct validity of each dimension.

\section{Organisational Structure Construct in Some Empirical Investigations}

The role of organisational structure as a determinant of various workplace outcomes is evident in many empirical findings. For instance, a study conducted by Nasurdin, Ramayah, and Yeoh (2006) found that formalisation has a positive influence on job stress. This is due to the fact that a job that is bounded by inflexible rules and procedures poses lesser autonomy and freedom for the incumbents on how to perform their tasks, which will most likely lead to job stress. In a cross-cultural study by Michaels, Dubinsky, Kotabe, and Chae (1996), it was found that formalisation inversely affects role ambiguity for the Americans but not the Japanese and Koreans. A plausible explanation for this result is because of the different work environments in the countries examined. In essence, Japanese and Korean workers are more collectivistic compared to their American counterparts, who are more individualistic. Formalisation is deemed necessary by American employees to provide them guidelines in managing job stress and conflict. It was also reported in this study that formalisation increases organisational commitment of Korean and Japanese sales personnel but role conflict has - a negative impact on their work alienation. On top of that, Michaels et al. (1996) provided that role conflict does not have influence on US salespersons because Americans enjoy working independently, and therefore, conflict does not have any impact on their commitment level. This study revealed that employees of different cultures may view organisational structures differently. Therefore, culture difference should be taken into account by the top management in deciding the level of organisational formalisation and centralisation to be adopted.

Organisational structure has created interest for a comparative study across sectors. For instance, Kim and Lee (2006) examined the influence

92 IJMS 17 (1), 87-106 (2010) 


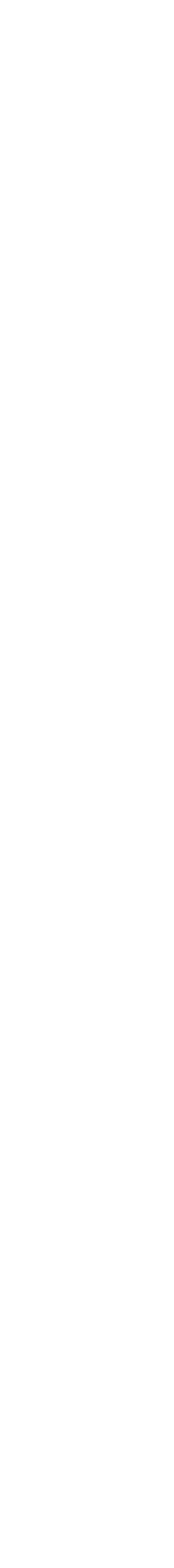

of organisational structure in terms of centralisation, formalisation, and performance-based reward systems on employee knowledge sharing capabilities in the public and private sectors in South Korea. As predicted, public servants reported higher mean scores for formalisation and centralisation and lower mean scores for clear vision and goals and performance based reward systems, and the level of knowledge sharing capabilities is higher among the private sector employees compared to the public sector counterparts. Kim and Lee (2006) contended that employee knowledge sharing capabilities differ between the two organisations because public sector managers face various organisational constraints in enhancing employee knowledge sharing capabilities. Organisational constraints were attributed to the higher level of formalisation and centralisation in the public sector. On the same note, Dean, Brandes, and Dharwadkar (1998) revealed that organisational formalisation may aggravate organisational cynicism, which has more deleterious effect. It starts with employees' own experience, such as lack of fair dealings, integrity, honesty, and sincerity among the top management in introducing rules, procedures, or policies in the organisation. This precipitates the feelings of distrust and disrespect among employees toward the organisation. Given all the empirical findings, it can be concluded that organisational structure is inversely related to various positive workplace outcomes.

The moderating role of organisational structure is also evident in many empirical investigations. For instance, Tata and Prasad (2004) studied the moderating impact of organisational characteristics, i.e. formalisation and centralisation on the self-management and team effectiveness relationship. Tata and Prasad (2004) categorised centralisation into macrolevel centralisation and micro-level centralisation, whereby the former deals with employees' participation in decision making regarding policies and procedures at the organisational level, and the latter concerns with employees' involvement in decision making regarding their own tasks. The first level supervisors and middle managers from the manufacturing companies responded in this study. Findings showed that teams with higher self-management appeared to be more effective in organisations that allow input from employees with regard to their task performance (micro-level decision making). On the contrary, macro-level decision making does not influence the strength of self-management and team effectiveness association at any level. Findings by Tata and Prasad (2004) also suggested that there is a stronger relationship between self-management and team effectiveness in organisations that have a lower level of formalisation. In other words, fewer rules, policies, and procedures allow flexibility in teams' self-management, which eventually boost teams' effectiveness. In addition to organisational, centralisation and formalisation, Tata and Prasad (2004) highlighted that there are three factors that may contribute to teams' effectiveness- team leader 
experience, clear goals, and adequate resources. Drawing on the findings, it can be concluded that flexibility encourages better team performance, especially at the micro-level decision making. To enhance team and individual effectiveness, employees should be given adequate freedom and autonomy in the decision making process, especially decisions that are related to their tasks. Another study adopted organisational characteristics as the moderating variable in exploring the leader power bases and subordinates' job satisfaction associations. Organisational formalisation and flexibility were incorporated into the moderating variable as a situational leadership construct. Five bases of power were examined in this study, but only expert power was tested as a contextual variable in relation to organisational formalisation and inflexibility. Yagil (2002) revealed that leader expert power and subordinates' job satisfaction are highly associated if the organisation practices lower levels of organisational formalisation and inflexibility. In other words, knowledge and skills provided by leaders are useful only if subordinates perceived it useful to their functioning. Subordinates may perceive clear, detailed, and rigid policies and procedures with regard to task and structure can be a substitute for the role of a leader. Hence, Yagil (2002) concluded that the level of powerfulness in leaders does not guarantee high influence on employees' behavioural and attitudinal outcomes. Instead, personal attributes, job characteristics, and organisational characteristics have a significant impact on subordinates' attitude or behaviours. Given the findings, organisational characteristics and job characteristics are among the important determinants of employees' attitude and behaviour.

Organisational structure has also been incorporated in some studies as a mediator. For example, empirical scrutiny by Kacmar, Bozeman, Carlson, and Anthony (1999) on Organisational Politics Model (Ferris et al., 1991) intended to expand and test alternative models by adding other constructs as the predicting and outcome variables while organisational politics remain as the mediating variable. Ferris et al.'s (1991) work on this model provides a comprehensive outlook in examining the organisational politics construct. The model integrates dimensions in organisational structure under different labels, which is organisational politics. The study examines the impact of organisational structure, job/work influences, and personal influence as the predicting variables. Although this model incorporates two moderators, understanding and control, Kacmar et al. (1999) explored the moderating effect of the former vis-à-vis the organisational politics-outcome relationships. Kacmar et al. (1999) reported organisational centralisation is positively related to perceived organisational politics. Highly centralised structure occurs when all decisions are made by the top management. Under such circumstance, politics in the organisation are rampant among employees so as to influence the decision makers. Kacmar et al. (1999) also noted that organisational politics have a significant influence on selfreported individual performance. Furthermore, the interaction effect of

94 IJMS 17 (1), 87-106 (2010) 


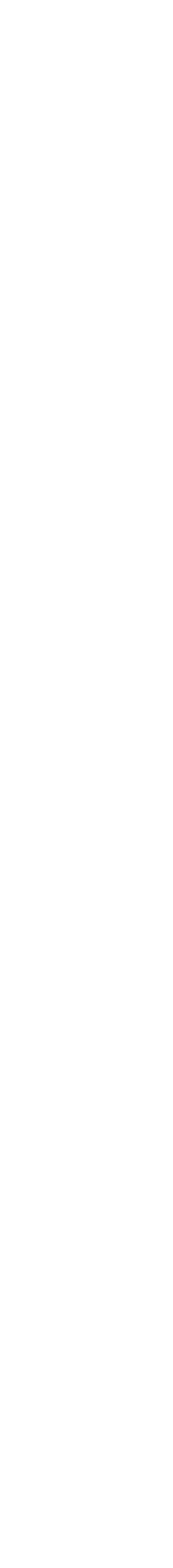

understanding is also significant in the explaining organisational politicsindividual performance association. In short, employees who have a better understanding on organisational processes, tend to perform better in their job, even when their perceptions of politics are high.

The negative influence of organisational structure on workplace outcome is also evident in the public sector setting. For instance, Pandey and Welch (2005) analysed Managerial Perception of Red Tape Model that includes aspects of organisational contexts and organisational environment in understanding their impacts on managerial perception of red tape. Instead of pointing fingers to public managers as the culprit to red tape practice, this model explores how managers cope with red tape in their organisations. Formalisation is one of the organisational contexts examined in this investigation, and it was found that high levels of job codification and rule observation have resulted in high levels of work alienation. This situation has also led to the negative perception of red tape among managers. Based on the findings, Pandey and Welch (2005) summed that managers with positive work attitudes are better able to overcome the red tape constraints. This is because their level of job involvement is high as compared to their counterparts with negative work attitudes. In other words, high job involvement hampers work alienation, which in turn, engenders coping ability with red tape among managers. Similarly, Sarros, et al. (2002) examined how leadership behaviour i.e. transformational and transactional, and organisational characteristics, i.e. centralisation and formalisation affect work alienation among officers in the US fire department. This research measured centralisation in terms hierarchy of authority while formalisation is distinguished into rule observation and job specificity. Sarros et al. (2002) also expanded the work alienation concept by dividing it into powerlessness, meaninglessness, and self-estrangement. Findings showed that hierarchy of authority exacerbates higher level of leadership behaviours, which subsequently lead to work alienation. For this reason, managers and supervisors have to allow for empowerment in the decision making process. This engenders the greater sense of autonomy, clarity, accomplishments, and freedom in their job (Sarros et al. 2002). In other words, leaders have to encourage participation from employees in the decision-making process so that the latter will find meaning in each task that they performed.

In this vein, Dean, et al. (1998) revealed that organisational formalisation may aggravate organisational cynicism, which has a more deleterious effect than work alienation. While the latter deals with employees negative feeling toward their job, organisational cynicism includes destructive attitudes, emotions, and behaviours that employees have toward the top management and organisation as a whole. It originates from employees' own experience, such as lack of fair dealings, integrity, honesty, and sincerity among the top management in introducing rules, procedures, or policies in the organisation. 
This precipitates the feelings of distrust and disrespect among employees toward the organisation. Dean et al. (1998) then contended that empirical investigations on outcomes of this construct in relation to organisational formalisation need to be explored further. Therefore, this study will attend to the suggestion by examining the role of formalisation in determining employees' performance.

Studies incorporating organisational structure also adopted different approaches in gathering data. For example, Kakabadse, Kakabadse, and Kouzmin (1999) used qualitiative methods to examine the countervailing effect of formalisation and centralisation on employees. Kakabadse et al. (1999) discovered that organisational formalisation and culture may bring about extra-role behaviour, which are ingratiation or organisational citizenship behaviour (OCB) among employees, depending on motive, perception of others, or both. Ingratiation is a negative behaviour, such that employees exhibit OCB with some ulterior motives. This is also known as a political tactics to influence their superiors, with the intention to fulfill their own personal motives. $\mathrm{OCB}$, on the other hand, is the real extra-role or discretionary behaviour that employees engage in. If managers sense that their subordinates are engaging in ingratiation, instead of $O C B$, they will then develop a negative perception toward the employees. In sum, Kakabadse et al. (1999) concluded that organisational formalisation and centralisation affect the self-managed teams' effectiveness level at a certain level. Too much of and inflexibility and decentralisation will result in group think, which is harmful to the organisation. Given this, Kakabadse et al. (1999) suggested that some form of control and monitoring, through formalisation and centralisation, are required to maximise self-managed teams' performance. In accordance to Kakabadse et al.'s (1999) findings, Johnson and Lenders (2001) contended that there is no perfect organisational structure that fits all large organisations. Organisations cannot be fully centralised or decentralised, but it must be in the form of a hybrid (combination of centralised and decentralised). For this reason, structures in any large organisations need to be revised from time to time depending on changes that occur in the external and internal environment. Drawing on this, Johnson and Leenders (2001) asserted that it is a challenge for managers to identify which structure that provides most benefits to employees as well as the company. In sum, this assertion provides new insight on the most appropriate organisational structure to be adopted. Based on the above reviews of literature, it can be concluded that many empirical studies were done to examine the outcome of organisational structure to various organisational constructs. This indicates that organisational structure is an important construct in predicting various organisational or workplace outcomes.

\section{Procedures}

Self-administered questionnaires were distributed to the respondents in four public service agencies in the state of Kedah, Malaysia. The researchers

96 IJMS 17 (1), 87-106 (2010) 


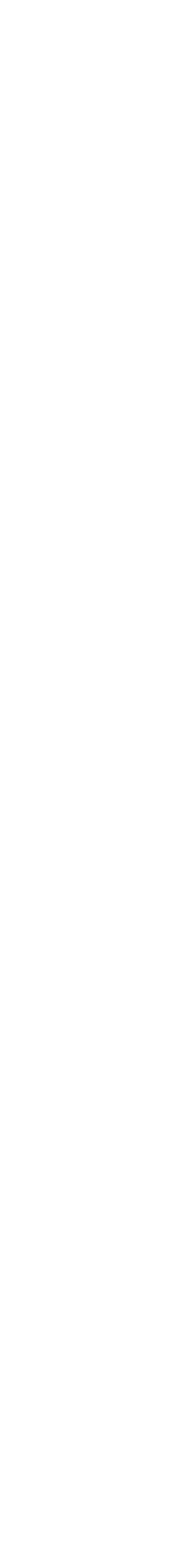

went to each agency and personally distributed the questionnaires to the chief clerk of each department, who were contacted prior to the researchers' visit. They were briefed on the research objectives and guidelines in answering the questionnaires. A total of 200 questionnaires were distributed and 103 were returned. However, only 100 questionnaires were usable for data analysis.

\section{Respondents}

Respondents were 100 public servants from four public service agencies in the state of Kedah. A total of 61 of the respondents were male and 39 were female. Because the Malaysian Public Service agencies in Kedah are predominantly Malay-populated, all of the respondents that participated in this study were Malays. Most of the respondents were the exempt employees, which made up $63.0 \%$ while $37.0 \%$ of the respondents were non-exempt employees. Questionnaires were given out to the respondents to answer 16 items on organisational structure.

\section{Decentering and Back Translation of Items}

Decentering was conducted whereby the original measurement was changed before it was adapted and back-translated. The purpose is to improve the translatability of the measurement whereby items that are likely to be specific to the original culture or context were removed or altered (Geisinger, 2003; Brislin, 1970). Two bilingual experts and one public service officer helped to identify some items in the measurement that needed to be refined to suit the Malaysian culture and public sector context. Then, the measurement was assessed to ensure that there is no culture-specific language or content.

The measurement was then translated from the English language into Malay language using back-translation procedure. Following Brislin (1970), Werner and Campbell (1970), and Geisinger (2003), two different bilingual language experts were used in the back-translation process. One of the experts translated the original items into Malay, and another expert re-translated the translated items into English without having seen the original text. After that, based on Geisinger (2003), the quality of the language translation was observed in terms of how accurately the back translated measurement agrees with the original version.

The back translated items were discussed and verified with officers and clerical staff from the public service departments and agencies to ensure suitability of all items in the public sector context. Another discussion was made with two human resource officers in one of the public service departments to get some feedback on the appropriateness of items adapted and translated, in measuring organisational structure in the public sector. This stage was crucial to guarantee content and face validity of all items used in the study. Based on the feedback, several improvements were made to the items. 


\section{Measurement of Organisational Structure}

Organisational structure refers to the formalisation and centralisation practised by the management of an organisation (Hage \& Aiken, 1967). All of the items were adapted from Hage and Aiken (1967). Decision making (four items) assessed opportunities given to employees to get involved in decision making. A sample item is "Management in this organisation always seeks inputs and feedbacks from employees in the process of making important decisions." Hierarchy of authority consisted of four items that measure the reliance of employees upon their supervisors in making their own decisions regarding their own work (e.g. "Little action can be taken until a supervisor approves a decision"). Job codification consisted of four items that examine the specifications of job descriptions or work standardisation (e.g. "Most people here make their own rules on the job"). Rule observation (two items) measured the type of supervision that employees get to ensure that they conform to the job codification standard. A sample item was "I feel as though I am constantly being watched to see if I obey all the rules". Centralised decision making was measured using four items and hierarchy of authority was measured using five items. Therefore, a total of nine questions were used to measure the formalisation construct. All of the items were adopted from Hage and Aiken (1967). Sarros et al. (2002) reported that both dimensions have high reliability coefficients of 0.92 and 0.96 respectively. Nasurdin et al. (2006) reported a quite high reliability coefficient of 0.87 . Deewar, Whetten, and Boje's (1980) study examined the measurement reliability based on Hage and Aiken studies in 1964, 1967, and 1970 showed alpha values of between 0.79 and 0.96 for both dimensions.

Five items were used to measure job codification and only two items were used to examine the rule observation construct. These items were adopted from Hage and Aiken (1967). Sarros et al. (2002) reported that both dimensions have moderate to high reliability coefficients of 0.76 and 0.93 respectively. Furthermore, Nasurdin et al. (2006) reported high reliability coefficient of 0.94. Deewar, Whetten, and Boje's (1980) study examined the measurement reliability based on Hage and Aiken studies in 1964, 1967, and 1970, and showed alpha values of between 0.72 and 0.93 for both dimensions. All items were rated on a seven-point Likert scale, namely $1=$ very disagree, $2=$ disagree, $3=$ slightly disagree, $4=$ moderate, $5=$ slightly agree, $6=$ agree, and $7=$ very agree. To determine the score of this scale, ratings within each scale are summed and divided by the total number of items in that particular scale. Negative statement items on the instrument were reverse-coded so that a high score on the instrument indicates a high degree of formalisation and centralisation in the departments and agencies studied. Table 1 shows items and source of items for dimensions in the organisational structure construct.

98 IJMS 17 (1), 87-106 (2010) 
Table 1

Items and Source of Items for Each Latent Constructs

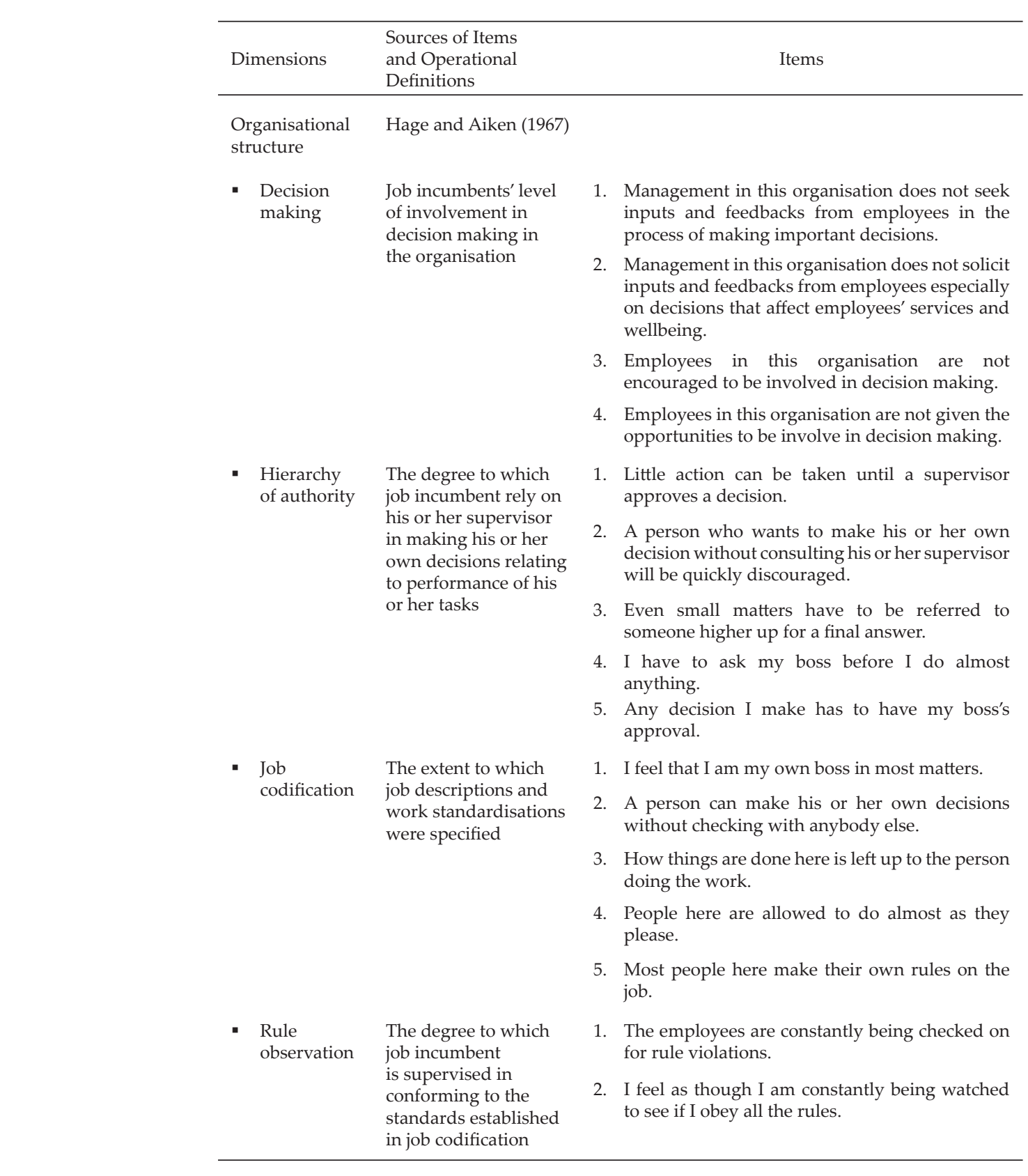

IJMS 17 (1), 87-106 (2010) 


\section{Results}

Both exploratory and confirmatory factor analyses were employed to examine the factor structure of the multidimensional organisational structure measurement scale. In this study, items for each observed variable was used to identify each of its latent variables.

\section{Reliability}

We first assessed the reliability of each scale measuring each dimension using the alpha coefficient. The values were observed prior to examining the validity of each scale through EFA and CFA. This is in accordance with Nunally (1967), who stated that reliability is a necessary condition for validity of the measure.

Table 2 presents the results of the internal consistency reliability, mean, and standard deviation for the total score and each subscale of the translated version of the measurement. Cronbach's alpha values ranged from 0.63 (Rule observation subscale) to 0.87 (Hierarchy of Authority subscale) for four dimensions. The internal consistency reliability for the overall Organisational Structure scale was 0.65.

Table 2

Summary Statistics for Organisational Structure and Cronbach's Alpha

\begin{tabular}{lccc}
\hline Dimension & \# of item & Mean & $\alpha$ \\
\hline Decision Making & 4 & 5.29 & 0.82 \\
Hierarchy of Authority & 5 & 5.47 & 0.87 \\
Job Codification & 5 & 2.44 & 0.76 \\
Rule Observation & 2 & 4.35 & 0.63 \\
Overall Organisational Structure & 16 & 4.48 & 0.65 \\
\hline
\end{tabular}

\section{Exploratory Factor Analysis}

The study examined the psychometric properties of the Malay language adaptation of the multidimensional organisational structure latent construct. Therefore, exploratory factor analysis was conducted to identify the factorial validity of each dimension (see Table 3). EFA in the study used a principal axis factoring extraction technique with direct oblique rotation and a priori criteria of factors based on the literature review. Principal axis factoring was chosen over other method of extraction because it is mostly used and understood (Tabachnick \& Fidell, 2007). Most importantly, principal axis factoring extraction analyses common variance among items while unique and error variances are eliminated (Byrne, 2001; Hair, Black, Babin, Andarson, \& Tatham, 2006; Tabachnick \& Fidell, 2007). Direct oblique rotation was used because all items shared the same second order factor and hence they are assumed to be correlated. Furthermore, the cutoff point for factor loadings in this study were 0.30 or greater because this threshold value was considered crucial in ensuring practical significance (Hair et al., 2006). 
Table 3

Factor Loadings for Organisational Structure

\begin{tabular}{|c|c|c|c|c|c|}
\hline \multirow{2}{*}{ Item } & \multirow{2}{*}{ Factor Loadings } & & & & \\
\hline & & 1 & 2 & 3 & 4 \\
\hline OS1 & $\begin{array}{l}\text { Management in this organisation } \\
\text { always seeks inputs and feedbacks from } \\
\text { employees in the process of making } \\
\text { important decision. }\end{array}$ & 0.676 & & & \\
\hline OS2 & $\begin{array}{l}\text { Management in this organisation always } \\
\text { solicits inputs and feedbacks from } \\
\text { employees especially on decisions that } \\
\text { affect employees' services and wellbeing. }\end{array}$ & 0.712 & & & \\
\hline OS3 & $\begin{array}{l}\text { Employees in this organisation are } \\
\text { encouraged to be involved in decision } \\
\text { making. }\end{array}$ & 0.764 & & & \\
\hline OS4 & $\begin{array}{l}\text { Employees in this organisation are always } \\
\text { given the opportunities to be involved in } \\
\text { decision making. }\end{array}$ & 0.780 & & & \\
\hline OS5 & $\begin{array}{l}\text { Little action can be taken until a supervisor } \\
\text { approves a decision. }\end{array}$ & & 0.806 & & \\
\hline OS6 & $\begin{array}{l}\text { An employee who wants to make his or } \\
\text { her decision without consulting his or her } \\
\text { supervisor will be quickly discouraged. }\end{array}$ & & 0.844 & & \\
\hline OS7 & $\begin{array}{l}\text { Even small matters have to be referred to } \\
\text { someone higher up for a final decision. }\end{array}$ & & 0.565 & & \\
\hline OS8 & $\begin{array}{l}\text { I have to ask my supervisor before I do } \\
\text { almost everything. }\end{array}$ & & 0.770 & & \\
\hline OS9 & $\begin{array}{l}\text { Any decision I make has to have my } \\
\text { supervisor's approval. }\end{array}$ & & 0.736 & & \\
\hline OS10 & I feel that I have full authority in my job. & & & 0.360 & \\
\hline OS11 & $\begin{array}{l}\text { I believe that an employee can make his or } \\
\text { her own decisions without checking with } \\
\text { anybody else. }\end{array}$ & & & 0.694 & \\
\hline OS12 & $\begin{array}{l}\text { How things are done in this organisation } \\
\text { is left up to the person doing the work. }\end{array}$ & & & 0.584 & \\
\hline OS13 & $\begin{array}{l}\text { Most employees in this organisation are } \\
\text { allowed to do almost as they please. }\end{array}$ & & & 0.791 & \\
\hline OS14 & $\begin{array}{l}\text { Most employees in this organisation make } \\
\text { their own rules on the job. }\end{array}$ & & & 0.568 & \\
\hline OS15 & $\begin{array}{l}\text { Employees in this organisation are } \\
\text { constantly being checked on for rule } \\
\text { violations. }\end{array}$ & & & & 0.484 \\
\hline OS16 & $\begin{array}{l}\text { I feel as though I am constantly being } \\
\text { watched to see if I obey all the rules. }\end{array}$ & & & & 0.728 \\
\hline Eigen Value & & 2.648 & 4.694 & 1.799 & 1.233 \\
\hline Variance Explained & & 13.826 & 6.749 & 8.316 & 4.817 \\
\hline Alpha & & 0.823 & 0.868 & 0.720 & 0.626 \\
\hline
\end{tabular}

IJMS 17 (1), 87-106 (2010) 101 


\section{Confirmatory Factor Analysis}

A confirmatory factor analysis was conducted to assess validity of the organisational structure measure. The standardised estimates were reported to interpret parameters in the measurement model. Following Byrne (2001), Hair et al. (2006), Schumacker and Lomax (2004), Tabahnick and Fidell (2007), the fit indices reported in the study are the root mean square residual (RMR) and root mean square error of approximation (RMSEA) for model fit, the Tucker-Lewis index (TLI) and the Comparative index (CFI) for model - comparison, and Normed Chi-Square (NC) or ratio for model parsimony.

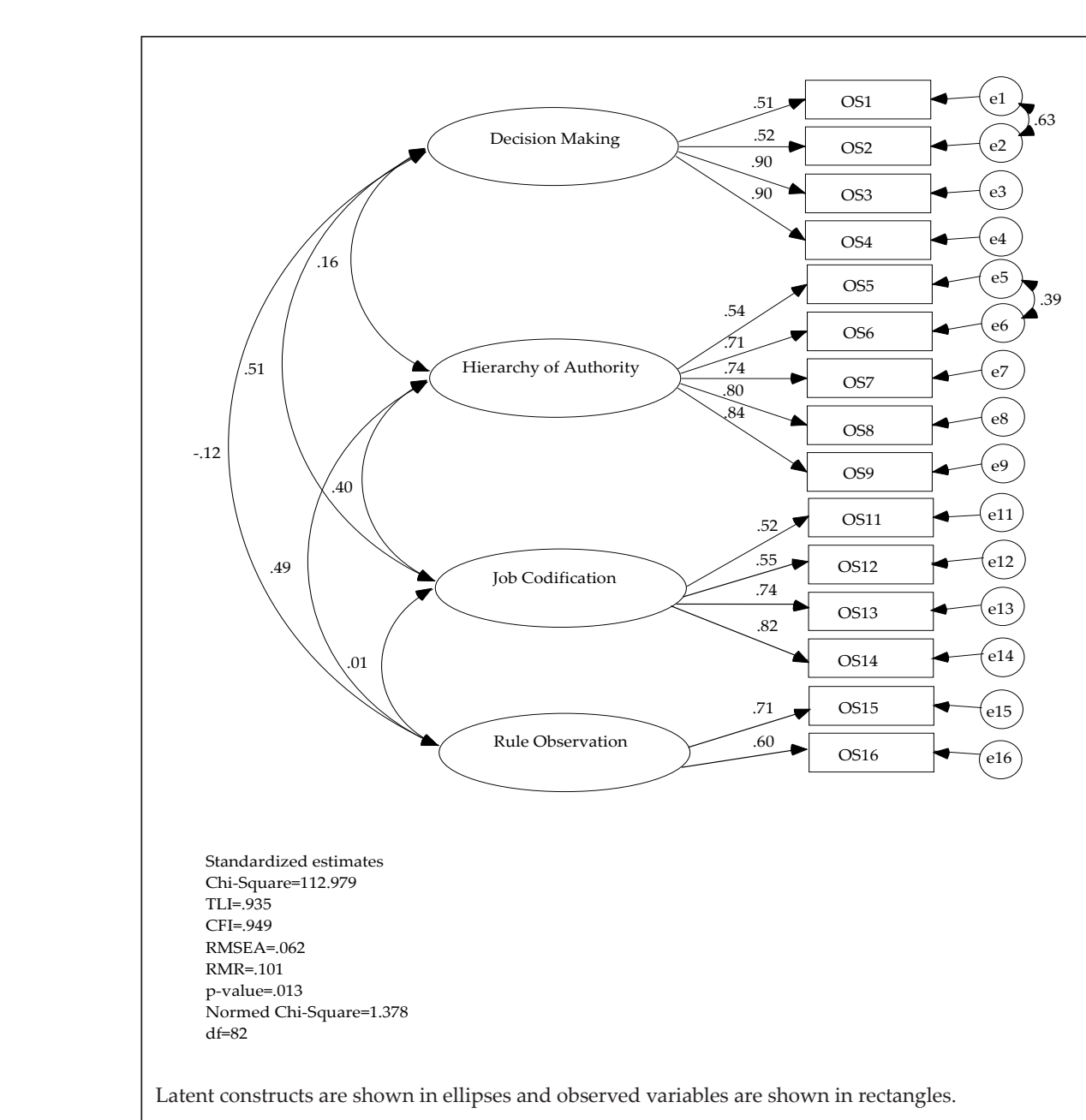

Figure 1. A first order measurement model for organisational structure. 


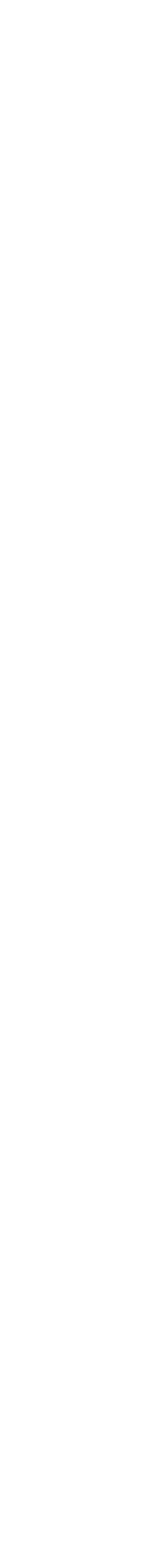

To indicate that the model is adequately fit, the cutoff values are 0.90 or higher for CFI and TLI (Byrne, 2001; Kline 2005; Schumacker \& Lomax, 2004), 0.08 or lower for RMSEA and 0.101 or lower for RMR (Byrne, 2001; Kline 2005; Schumacker \& Lomax, 2004). The acceptable range is between 1 and 5 for normed chi-square (Schumacker \& Lomax, 2004).

As indicated in Figure 1, the value of ratio or normed chi-square was 1.378 $\left(\chi^{2}=112.979, \mathrm{df}=82, \mathrm{p}=0.013\right)$. The value of CFI is 0.949 and TLI is 0.935 . Figure 1 also shows that all loadings of items on their targeted factors were high, statistically significant, and above 0.30 , the cutoff point used in the exploratory factor analysis. Specifically, the standardised factor loadings were between 0.51 and 0.90 , lending support for the convergent validity of the model. The four factors were correlated with the correlation value ranging from 0.01 to 0.51 , suggesting that these factors are interrelated but are relatively orthogonal of one another.

\section{Conclusions}

The measurement of organisational structure construct developed by Hage and Aiken (1967) can be used in the Malaysian studies because findings showed the evidence of construct validity of all items in the instrument. Results of this study also reported that coefficient alphas were more than 0.60 for all subscales and exploratory factor analysis indicated support for the factorial validity of the organisational structure scale. Such findings suggested acceptable reliability and validity of the instrument. Furthermore, confirmatory factor analysis provided the evidence of construct validity based on tests of significance and assessment of the measurement model fit. Thus, four subscales of organisational structure can be useful instruments in examining the organisational structure construct in the Malaysian setting. The study has given a significant contribution in terms of construct development of a more comprehensive organisational structure measure. Given the psychometric properties of the organisational structure instrument, which are very acceptable, i.e. both constructs equal or exceed the measurement levels, this instrument can be used by Malaysian researchers in measuring organisational structure as all of the items that measure the construct it was supposed to measure.

\section{References}

Adler, P.S., \& Borys, B. (1996). Two types of bureaucracy: Enabling and coercive. Administrative Science Quarterly, 41(1), 61-89.

Agarwal, S. (1993). Influence of formalisation on role stress, organisational commitment, and work alienation of salesperson: A cross-national comparative study. Journal of International Business Studies, 24(4), 715739.

IJMS 17 (1), 87-106 (2010) 
Black, S., Briggs, S., \& Keogh, W. (2001). Service quality performance measurement in public / private sectors. Managerial Auditing Journal, 16(7), 400-405.

Bodewes, W.E. (2002). Formalisation and innovation revisited. European Journal of Innovation Management, 5(4), 214-223.

Brislin, R.W. (1970). Back-translation for cross cultural research. Journal of Cross Cultural Psychology, 1, 185-216.

Byrne, B.M. (2001). Structural equation modelling with AMOS. Mahwah, NJ: Lawrence Erlbaum Associates.

Dean, J.W., Brandes, P., \& Dharwadkar, R. (1998). Organizational cynicism. Academy of Management Review, 23(2), 341-352.

Deewar, R. D., Whetten, D. A., \& Boje, D. (1980). An examination of the reliability and validity of the Hage and Aiken scales of centralization, formalization, and task routineness. Administrative Science Quarterly, 25(1), 120-128.

Geisinger, G.F. (2003). Testing and assessment in cross-cultural psychology. In J. R. Graham, J.A. Naglieri, \& I.B. Weiner (Eds.), Handbook of psychology: Vol.10. Assessment Psychology, (95-118). Hoboken, NJ: John Wiley \& Sons.

George, B. P., \& Hegde, P. G. (2004). Employee attitude towards customers and customer care challenges in banks. International Journal of Bank Marketing, 22(6), 390-406.

George, J. M., \& Jones, G. R. (1997). Organizational spontaneity in context. Human Performance, 10(2), 153-170.

Givan, R.K. (2005). Seeing stars: Human resources performance indicators in the National Health Service. Personnel Review, 34(6), 634-647.

- Hage, J., \& Aiken, M. (1967). Relationship of centralisation to other structural properties. Administrative Science Quarterly, 72-92.

Hair, J.F., Black, W.C., Babin, B.J., Anderson, R.E., \& Tatham, R.L. (2006). Multivariate data analysis (6th ed.), Uppersaddle River, NJ: Pearson Prentice Hall.

Heneman, H.G., \& Judge, T.A. (2003). Staffing organizations (4th ed.), Middleton, MI: McGraw Hill.

IMD world competitiveness report. (2005). IMD World Competitive Center. Retrieved February 21, 2007, from http://www.imd. $\mathrm{ch} /$ research/publications/wcy/wcy_online.cfm?mrk_cmpg source $=1007138 \&$ bhcp $=1$

IMD world competitiveness report. (2006). IMD World Competitive Center. Retrieved February 21, 2007, from http://www.imd. $\mathrm{ch} / \mathrm{research} /$ publications/wcy/wcy_online.cfm?mrk_cmpg source $=1007138 \&$ bhcp $=1$

IMD world competitiveness report. (2007). IMD World Competitive Center. Retrieved November 4, 2007, from http://www.imd. $\mathrm{ch} / \mathrm{research} /$ publications/wcy/wcy_online.cfm?mrk_cmpg_ source $=1007138 \&$ bhcp $=1$ 
Johnson, P.F., \& Leenders, M.R. (2001). The supply organisational structure dilemma. The Journal of Supply Chain Management, Summer 2001, 4-11.

Kacmar, M.K., Bozeman, D.P., Carlson, D.S., \& Anthony, W.P. (1999). An examination of the perceptions of organisational politics model: Replication and extension. Human Relations, 52(3), 383-416.

Kakabadse, N.K., Kakabadse, A.K., \& Kouzmin, A. (1999). Dysfunctionality in "citizenship" behavior in decentralized organizations: A research note. Journal of Managerial Psychology, 14(7), 526-544.

Kim., S., \& Lee, H. (2006). The impact of organisational context and information technology on employee knowledge sharing capabilities. Public Administration Review, May/June 370-385.

Kline, R.B. (2005). Principles and practice of structural equation modeling (2nd ed.) New York, NY: The Guilford Press.

Malek, S. (2006, August 21). Transforming human capital for public service excellence in the $21^{\text {st }}$ century. Speech presented for the $11^{\text {th }}$ Civil, Service Conference, National Institute of Public Administration, Bukit Kiara, Kuala Lumpur.

Michaels, R.E., Dubinsky, A.L., Kotabe, M., \& Chae, U.L. (1996). The effects of organizational formalization on organizational commitment and work alienation in US, Japanese, and Korean industrial salesforces. European Journal of Marketing, 30(7), 8-24.

Motowidlo, S.J., Borman, W.C., \& Schmit. M.J. (1997). A theory of individual differences in task and contextual performance. Human Performance, 10(2), 71-84.

Mwita, J.I. (2000). Performance management model: A system based approach to public service quality. International Journal of Public Sector Management, 13(1), 19-37.

Nasurdin, M.A., Ramayah, T., \& Yeoh, C.B. (2006). Organizational structure and organizational climate as potential predictors of job stress: Evidence from Malaysia. International Journal of Commerce $\mathcal{E}$ Management, 16(2), 116-129.

Nunnally, J.C. (1967). Psychometric theory. New York, NY: McGraw-Hill.

Pandey S.K., \& Rainey, H.G. (2006). Public managers' perception of organizational goal ambiguity: Analyzing alternative models. International Public Management Journal, 9(2), 85-112.

Pandey, S.K., \& Welch, E.W. (2005). Beyond stereotypes: A multistage model of managerial perceptions of red tape. Administration and Society, 37(5), 542-575.

Public Complaints Bureau (2004). PCB statistics 2005. Putrajaya:Author. Retrieved February 22, 2007, from http://www.bpa.jpm.my/Annual / STATISTIK\% 20TAHUN\%2020041_BI.pdf

Public Complaints Bureau (2005). PCB statistics 2005. Putrajaya:Author. Retrieved February 22, 2007, from http://www.bpa.jpm.my/Annual / STATISTIK\% 20TAHUN\%2020051_BI.pdf 
Public Complaints Bureau (2006). PCB statistics 2005. Putrajaya:Author. Retrieved February 22, 2007, from http://www.bpa.jpm.my/Annual / STATISTIK\% 20TAHUN\%2020061_BI.pdf

Public Complaints Bureau (2007). PCB statistics 2007. Putrajaya:Author. Retrieved November 4, 2007, from http://www.bpa.jpm.my/Annual / STATISTIK\% 20TAHUN\%2020071_BI.pdf

Public Service Department (2007). Maklumat perjawatan dan pengisian sektor awam. Putrajaya: Author. Retrieved 4 March, 2007, from http://www. jpa.gov.my/i-mapsa/ Default.aspx? alias=www.jpa.gov.my/i-mapsa/ perangkaan

Rhoades, L., \& Eisenberger, R. (2002). Perceived organizational support: A review of the literature. Journal of Applied Psychology, 87, 698-714.

Sarros, J.C., Tanewski, G.A., Winter, R.P., Santora, J.C., \& Densten, I.L. (2002). Work alienation and organizational leadership. British Journal of Management, 13, 285-304.

Schumacker, R.E., \& Lomax, R.G. (2004). A beginner's guide to structural equation model (2nd ed.) Mahwah, NJ: Lawrence Erlbaum Associates.

Siddiquee, N.A. (2006). Public management reform in Malaysia. International Journal of Public Sector Management Journal, 19(4), 339-358.

Speier, C., \& Frese, M. (1997). Genralized self-efficacy as a mediator and moderator between control and complexity at work and personal initiative: A longitudinal field study in East Germany. Human Performance, 10(2), 171-192.

Tabachnick, B.G., \& Fidell, L.S. (2007). Using multivariate statistics (5th ed.). Boston, MA: Pearson Education.

Tata, J., \& Prasad, S. (2004). Team self-management, organizational structure, and judgment of team effectiveness. Journal of Managerial Issues, 16(2), 248-65.

Werner. O., \& Campbell, D.T (1970), Translating, working through interpreters and the problem of decentering. In Cohen, R.N (Eds). A Handbook of Methods in Cultural Anthropology, New York, NY: American Museum of Natural History.

Williams, R.S. (2002). Managing employee performance: Design and implementation in organizations. London: Thompson Learning.

- Wrong, D. (Ed.) (1970). Max Weber. Englewood Cliffs, NJ: Prentice Hall.

Yagil, D. (2002). Substitution of a leader's power bases by contextual variables. International Journal of Organizational Theory and Behavior, 5(3), 383-399. 